\title{
PIOTR GOŁDYN*
}

\section{Zagadnienia pedagogiczne i oświatowe na łamach „Głosu Konińskiego” (1921-1939)}

Informacje o życiu społecznym w regionie konińskim (w tym o oświacie) pojawiały się już w XIX w. na łamach prasy ogólnopolskiej czy później gubernialnej (Kalisz). W samym Koninie pierwsze próby wydawania lokalnej prasy podjęto w roku 1914, w pierwszych dniach okupacji niemieckiej. Od tego czasu jeszcze kilkukrotnie podejmowano inicjatywy wydawnicze, a były to przede wszystkim periodyki urzędowe władz powiatowych. Po odzyskaniu niepodległości, w roku 1918 kontynuowano tego typu wydawnictwa, wydając między innymi „Tygodnik Urzędowy. Organ Starostwa Konińsko-Słupeckiego”. Był to początkowo periodyk typowo urzędowy, z czasem zaczął jednakże zmieniać charakter, publikując również inne informacje. W następnych latach zmieniał on jeszcze swój profil, a wynikało to między innymi ze zmian w prawie ${ }^{1}$.

Pierwszy numer „Głosu Konińskiego” ukazał się 6 maja 1921 r. Oprócz kolejnej zmiany tytułu, zmieniono również formułę i publikowano coraz więcej informacji lokalnych. W ten sposób w Koninie i powiecie zaczęła funkcjonować lokalna prasa. Komitet Redakcyjny napisał wówczas: „Zacieśnienie działu Urzędowego do granic niezbędnych umożliwi wszechstronne omówienie spraw społecznych"2. Gazeta ukazywała się raz w tygodniu, najczęściej z sobotnią datą, choć pojawiały się w tym zakresie zmiany ${ }^{3}$.

Wśród treści społecznych niepoślednią rolę zajmowały kwestie związane z oświatą i wychowaniem. Publikowano artykuły dotyczące zagadnień pedagogicznych sensu stricte, ale także te odnoszące się do spraw oświatowych, a więc funkcjonowania szkół, budowy i otwierania nowych. Zakres zatem był różny. Dokładna analiza treści artykułów pedagogicznych i oświatowych, zwłaszcza tych ostatnich, daje obraz niekompletny, co prawda, funkcjonowania szkolnictwa

* Dr, Centrum Doskonalenia Nauczycieli w Koninie, 62-510 Konin, ul. Sosnowa 14.

1 P. Rybczyński, Wydawnictwo GK w latach 1921-1939, [w:] Głos Koniński. Materiały źródłowe do dziejów Konina, CD-ROM, Konin 2009, s. 3.

2 Od redakcji, „Głos Koniński” [dalej: GK] 1921, nr 1, s. 1.

3 P. R y b czyń s ki, Wydawnictwo..., s. 5-6. 
powszechnego i średniego w Koninie i powiecie konińskim w dwudziestoleciu międzywojennym.

Treści pedagogiczne i oświatowe publikowane były na łamach gazety dość często, choć nieregularnie. Były lata, w których niemal w każdym numerze zamieszczano artykuły bądź krótkie informacje oświatowe i pedagogiczne, ale były też lata, że trudno znaleźć jakiekolwiek wzmianki w tym zakresie. Sporadycznie pojawiały się tematy dotyczące oświaty w innych krajach lub częściach Polski. Częściej jednak podejmowano tematy lokalne, które były niezwykle istotne dla lokalnej społeczności, które również dziś są ważne w kontekście regionalnych badań nad dziejami oświaty.

\section{Treści pedagogiczne}

Fakt, że treści pedagogiczne stały się jednym z ważnych tematów publikowanych na łamach „Głosu Konińskiego" potwierdza już pierwszy numer. W nim bowiem ukazał się artykuł pt.: Nasze wychowanie. Autor zwraca uwagę na konieczność współpracy szkoły z domem i domu ze szkołą w dziele wychowania młodego człowieka. Uważa on, że jest ona niezadawalająca lub nie ma jej wcale, a najlepsze efekty są możliwe do osiągnięcia tylko we wspólnym działaniu i szkoły, i rodziców. „[...] do chwili, gdy dziecko przestępuje progi szkolne, pozostaje ono pod bezpośrednim wpływem rodziców, na których spada w pierwszym rzędzie obowiązek wychowawczy. Lecz i wtedy nawet, gdy już i szkoła przyjmie na siebie część tego zadania przy pomocy swego głównego środka wychowawczego, jakim jest nauka - rodzice powinni w dalszym ciągu wspólnie ze szkołą współpracować nad wychowaniem dziecka. Nie jest bowiem możliwe osiągnięcie wychowania za pomocą samej szkoły lub też samej rodziny. Wychowanie to rzeźbienie duszy ludzkiej. Dusza dziecka to złom surowego marmuru. [...] Dom i szkoła mają stać się tym artystą, umiejącym kuć w sercach dziatwy charaktery marmurowe, krystaliczne. Jedynie we wspólnej pracy, wspólnemi siłami domu i szkoły udać się może to trudne dzieło wychowania. Jedynie jednolite oddziaływanie domu i szkoły na młodzież, łączność domu rodzicielskiego ze szkołą może dać dodatnie rezultaty"4.

Dalej autor wini obie strony - i szkołę, i dom - za brak współpracy. Rodzicom zarzuca podważanie autorytetu nauczycieli i szkoły oraz niechęć do poznania celów, jakie przyświecają szkole w działaniach, traktując szkołę i nauczyciela jako wroga. Szkołę z kolei obwinia za brak zaufania do rodziców. Interesujący jest fakt, iż mimo upływu prawie stu lat od publikacji tego krótkiego artykułu w zasadzie nic się nie zmieniło, nadal dąży się do wypracowania nici porozumienia i płaszczyzn współpracy pomiędzy szkołą a domem.

„Lekcja w szkole powszechnej na wsi. Jedno z dzieci wyrywa się ze skargą na kolegę: «Proszę pana nauczyciela, ale Adaś to tak brzydko powiedział»...

${ }^{4}$ Nasze wychowanie (dom a szkoła), GK 1921, nr 1, s. 1-2 [Zostaje zachowany oryginalny zapis tekstów cytowanych w całym artykule.]. 
Oskarżony i świadkowie zostają po lekcjach i nauczyciel dowiaduje się ze zgrozą, że przez usta dziewięcioletniego dziecka wiejskiego przechodzą wyrazy tak wyuzdane, do najwyższego stopnia brzydkie i niemoralne, że gdyby słyszał je, nie widząc mówiącej osoby, sądzićby musiał, że wypowiedziane zostały przez człowieka zepsutego do gruntu. Tymczasem wypowiedziało je dziecko z duszą jeszcze nie zepsutą, którą jednakże wychowanie domowe i stosunki pozaszkolne zaczynają paczyć i zatruwać. Zapytany, dlaczego tak mówił, dzieciak wcale niezafrasowany daje znamienną odpowiedź: «Bo... bo mama też tak mówi»"5.

Taką historyjką zaczyna się krótki artykulik, w którym autor po raz kolejny zwraca uwagę na potrzebę współpracy domu ze szkołą w zakresie wychowania dzieci. Zachęca rodziców, mimo natłoku ich obowiązków, do poświęcenia choćby chwili uwagi dzieciom. Uświadamia również, że niejednokrotnie rodzice niweczą swoją postawą i zachowaniem wysiłki szkoły. Warto zwrócić uwagę na interesujące porównanie dziecka zawarte w tekście. „Dusza dziecka podobna jest do walizy podróżnej. Jeżeli dziecko na swej drodze życia znajdzie rzeczy piękne, szlachetne i dobre - chowa je i niesie ze sobą przez całe życie, one stanowią jego jaźń wewnętrzną, one są materiałem, z którego kształtuje się przyszły człowiek. Jeżeli zaś spotka rzeczy złe, zabierając je, brudzi swą duszę, czyni ją niedostępną dla dobra i światła"

Pojawiały się także artykuły, w których wskazywano na metody, konieczne do osiągnięcia dobrych efektów wychowawczych. Za jedną z nich uważano pracę fizyczną, która według autora artykułu praktykowana była już w starożytnej Grecji jako element podporządkowania siły fizycznej ideałom duchowym. Za przykład stawiał też ówczesną Anglię, jako czołową przedstawicielkę nowożytnej kultury, gdzie szeroko pojęte wychowanie fizyczne było podstawą wychowania. W dalszej części uzasadniał potrzebę wprowadzenia pracy fizycznej w polskiej szkole, twierdząc, że o wiele istotniejsze jest wyrobienie charakterów niż inteligencji. Tą pracą fizyczną miały być zajęcia warsztatowe, które z jednej strony dałyby odpoczynek od pracy umysłowej, a z drugiej wyrabiały zamiłowanie do pracy i być może były ukierunkowaniem młodego człowieka do wyboru kariery innej niż urzędnicza. Kariery w przemyśle, rzemiośle, w tych dziedzinach, które należało rozwijać w odradzającym się państwie ${ }^{7}$.

Na łamach „Głosu Konińskiego” można było również, choć sporadycznie, przeczytać pewnego rodzaju pouczenia o charakterze dydaktycznym uczniów podejmujących działania na rzecz własnych szkół. W artykule zatytułowanym Literatura uczniowska autor skupił się na gazetce wydawanej przez uczniów konińskiego gimnazjum żydowskiego. Zwrócił uwagę na niepoprawny zapis odnoszący się do samego tytułu Uczniowska Myśl. „Przedewszystkiem czemu „Uczniowska Myśl". To szyk rosyjski - Ruskaja Myśl: ruskoje słowo, narodnojo dieło; po polsku mówimy, myśl polska, słowo polskie, sprawa narodowa" ${ }^{\text {. }}$ W dalszej części wytknięto jeszcze kilka innych błędów, ogólnie jednak stwierdzono, że młodym ludziom redagowanie tego typu wydawnictw szkolnych przynosi dużo korzyści.

\footnotetext{
${ }^{5}$ J. W i ś., Wychowanie pozaszkolne, GK 1922, nr 14, s. 2.

6 Tamże.

7 Znaczenie pracy fizycznej w wychowaniu, tamże, nr 8, s. 1-2.

8 Literatura uczniowska, GK 1921, nr 8, s. 1.
} 
W październiku 1927 r. ukazał się na łamach „Głosu Konińskiego” apel inspektora szkolnego, który domagał się od władz miasta dokończenia budowy gmachu szkoły powszechnej. Bardziej palącym problemem była edukacja dzieci w wieku przedszkolnym, której w Koninie brakowało. „A tu pracy jest moc i to pracy, która jest piekącą i wymaga bezzwłocznego zajęcia się nią. W zakresie szkoły taką jest sprawa wychowania przedszkolnego, któreby objęło dzieci 5 i 6 letnie, ten narybek, który uchronić należy w tych najpiękniejszych dniach rozwoju duchowego od wpływu ulicy, rynsztoków, w których uczy się najgorszych instynktów, jakie zrodzić może zło. [...] Zachwaszczają też te nawyki z rynsztoku tak dusze dziecięce, że nie mogą zwalczyć ich świetlane obrazy, jakim przygląda się dziecko w szkole. Musi tedy wcześniej objąć się dziecko wpływem wychowawczym. Musimy naginać tę latorośl już od chwili, gdy umysł jego jest nieskażony, by przygotować go na błogi wpływ szkoły"9.

W dalszej części tekstu autor podaje jeszcze wiele innych argumentów przemawiających za koniecznością objęcia wychowaniem przedszkolnym konińskich dzieci, ale zdaje sobie sprawę, że możliwe to będzie dopiero po ostatecznym oddaniu gmachu szkoły. Stąd też na koniec powtarza apel do władz miasta o podjęcie działań, celem dokończenia budowy szkoły.

Apel ten znalazł oddźwięk zarówno wśród władz miasta, jak i społeczeństwa i nieco ponad rok później, tj. 17 listopada 1928 r. w Koninie przy ul. Kolskiej otwarte zostało i poświęcone przedszkole dla najuboższych dzieci z miasta. Do przedszkola przyjęto 35 dzieci, które oprócz opieki, wychowania otrzymywały również dwa posiłki dziennie (śniadanie i obiad), odciążając tym samym budżety domowe. Nie ukrywano, że głównym inicjatorem otwarcia przedszkola był inspektor szkolny, któremu w udziale przypadło także wygłoszenie przemówienia inauguracyjnego. Było to niezwykle ważne wydarzenie w dziejach oświatowych miasta, a reakcję gości autor relacji opisał następująco: „Naprawdę wzruszenie ogarniało każdego, gdy patrzył na małe krzesełeczka, stoliki, miseczki i garnuszki, na ten cały światek dziecięcy. Serca obecnych żywiej drgały, gdy pomyśleli sobie, że w tym tak niedawno pustym i ponurym lokalu rozlegać się będzie beztroski śmiech dziecięcy, tych właśnie dzieci, które nie z własnej winy poza płaczem, a często i głodem innych rozrywek w życiu nie znają. Cześć niechaj będzie temu, z którego inicjatywy i niestrudzonej pracy społecznej stworzone zostało to dzieło, cześć za to, że pomyślał przedewszystkiem o „dzieciach ubóstwa”, na dalszy plan odkładając troskę o „dzieci-bóstwa”"10. Przedszkole to było formą żywego pomnika z okazji dziesiątej rocznicy odzyskania niepodległości, stąd nosiło nazwę „Przedszkole im. 11 listopada w Koninie".

Analizując treści pedagogiczne publikowane na łamach „Głosu Konińskiego" nie sposób ominąć interesującego artykułu poświęconego umysłowej higienie dziecka, skierowanego w głównej mierze do matek. W artykule tym autor przypominał podstawowe prawidła wychowawcze, gdzie dom i dobry przykład stanowią zaczyn kształtowania ludzkiego charakteru. Matkom wyłuszczył główne prawdy wychowawcze, które są niezwykle aktualne również współcześnie, stąd warto w tym miejscu jej przypomnieć:

\footnotetext{
9 J. B o r zę c k i, Do Świetnej Rady Miejskiej w Koninie, GK 1927, nr 40, s. 1-2.

${ }^{10}$ Niezwykła uroczystość, GK 1928, nr 47, s. 1-2.
} 
„a) Należy dzieci uczyć odpowiedniego postępowania, ale nie powinno się zdążyć do tego drogą zawstydzania ich i onieśmielania. Wstyd nie jest zdrowem i pożądanem wzruszeniem i nie powinno się go wyrabiać w dziecku, podobnie jak nie powinno się wyrabiać w dziecku upokorzenia, zakłopotania i bolesnej wprost nieśmiałości w obecności drugich osób.

b) Dzieci nie powinno się nigdy straszyć. Straszenie dzieci jest rzeczą poważną, a jednak wiele osób dorosłych lubi sobie robić z tego żarty. Straszenie dziecka może pociągnąć za sobą bardzo smutne dla niego następstwa.

c) Wobec dzieci nie powinno się kłamać, zwłaszcza w ważnych sprawach, takich jak sprawa płci. Kłamliwe i oszukańcze wyjaśnienia prędko są sprawdzane przez dzieci, a doświadczenia przy których odkrywają owe prawdy, są niezmiernie zgubne dla nich. Na zapytania dzieci w tych sprawach trzeba odpowiadać otwarcie i bez zakłopotania, odpowiednio do zdolności dziecka, pozwalając mu na zrozumienie odpowiedzi.

d) Należy dokładać wszelkich starań, by nie wyrabiać w dziecku uczucia niższości; gdyż to przynosi duże szkody w poźniejszem jego życiu.

e) Zachodzą takie wypadki, że dziecko trzeba ukarać. Dziecko można karać w taki sposób, który jest dla niego dobroczynny. $Z$ drugiej strony niemądre karanie dziecka może pociągnąć za sobą bardzo nieszczęśliwe następstwa. Kara powinna być sprawiedliwa, rozumna i szybka. Nie powinna być wynikiem gniewu, albo kaprysu ojca czy matki, bez uwzględnienia uczucia sprawiedliwości, jakie istnieje u dziecka. Kara, która jest tylko wynikiem gniewu ojca lub matki, wywołuje nienawiść i bunt przeciwko autorytetowi ojca, czy matki, utrwala się w duszy dziecka i w końcu staje się wzruszeniowym nałogiem, prowadzącym do poważnych trudności w późniejszym życiu.

f) Przy wychowywaniu dziecka należy zapewnić mu o ile możności jak największą swobodę do wyrażania i uzewnętrzniania swej indywidualności w jego zabawach, jego pracy i stosunkach z innemi członkami rodziny. Jeżeli to zachowanie się i wyrażanie swej indywidualności jest niemądre, niebezpieczne, lub też narusza prawa innych osób, mądry ojciec lub matka skieruje energję dziecka w inną, bardziej odpowiednią stronę, bez użycia siły i wywoływania w niem uczucia musu, które nie oddziaływa odpowiednio na zdrowy rozwój duchowy dziecka.

g) Trzeba pomóc dziecku do wyrobienia i utrzymania szacunku dla siebie samego. Nie wolno ani słowem, ani uczynkiem odbierać mu tego szacunku”11.

W podobnym duchu wypowiedział się autor artykułu opublikowanego w roku 1936. Tam również zwracano uwagę na powinności wychowawcze rodziców. Sugerował, że nie można ignorować dzieci i nie odpowiadać na ich pytania, zbywając np. brakiem czasu ${ }^{12}$.

Inną kwestią pedagogiczną poruszoną na łamach „Głosu Konińskiego” było wychowanie poprzez zabytki, poprzez regionalizm. Przy czym dla autora artykułu zabytki nie ograniczały się tylko do budynków czy cmentarzysk, ale również do wytworów kultury, jak pieśni, wierszy, tańców czy szeroko rozumianej sztuki ludowej. Dzięki znajomości, dzięki poznaniu tego typu zabytków można pogłębić swoją

11 J. W i ś., Umysłowa hygjena dziecka, GK 1925, nr 16, s. 1-2.

12 Hodowla czy wychowanie?, GK 1936, nr 15, s. 3. 
miłość i swoje poświęcenie dla Ojczyzny. Regionalizm i tradycja lokalna były ważnymi czynnikami wychowawczymi, bowiem „sama nawet świadomość, iż się wie coś o swej wsi, czy mieście, czy o tym, że w swoim środowisku w dawnych czasach była kiedyś szkoła i niosła światło i kulturę - już budzi uczucie dumy i chęć podtrzymywania tradycji”'13.

\section{Sprawy nauczycieli}

Na łamach „Głosu Konińskiego" nie omijano spraw dotyczących nauczycieli, ich pracy, funkcjonowania w środowisku lokalnym czy postaw patriotycznych. W jednym z pierwszych numerów "Głosu Konińskiego” z 1922 r. pojawiła się informacja o strajku nauczycieli, którzy po przerwie świątecznej nie wrócili do pracy, chcąc tym samym wymóc podwyżkę płac. Było to 10 stycznia 1922 r. i było to drugie tego typu zajście w Koninie. Jako pierwsi zastrajkowali w roku 1921 nauczyciele gimnazjum żydowskiego, jednakże lokalna prasa przemilczała to wydarzenie, uważając je za bardzo wstydliwe. W tym jednakże przypadku redakcja wyraziła swoje niezadowolenie i oburzenie „ze wstydu, że ludzie inteligentni zdolni są do takiego sposobu postępowania"14.

Niezwykłe poruszenie i niemałą sensację wzbudziła sprawa w konińskim Sądzie Pokoju „z powództwa p. Ślusarskiego, nauczyciela gimnazjum humanistycznego i jednocześnie dyrektora średniej szkoły żeńskiej o zniesławienie go przez p. Wołoszczuka, kolegę, na zabraniu rodziców w gimnazjum po skończonym popisie szkolnym" ${ }^{15}$. Spór ten był konsekwencją nieporozumień, które trwały w konińskich szkołach średnich od stycznia, od wspomnianego wcześniej strajku. Po wysłuchaniu stron i świadków sprawa zakończyła się sądem honorowym i została w konsekwencji umorzona ${ }^{16}$.

„Głos Koniński” informował również o przykrych wydarzeniach dotyczących nauczycieli. Na łamach gazety zamieszczano nekrologi bądź wspomnienia pośmiertne. W roku 1922 ukazała się krótka notka informująca o pogrzebie 23-letniego nauczyciela. „W sobotę 20 maja odbył się w Koninie pogrzeb ś. p. Aureljusza Wiśniewskiego, nauczyciela szkoły powszechnej we wsi Polichnie gm. Władysławów, przy udziale duchowieństwa in gremio, nauczycielstwa i tłumnie zebranej publiczności. Zmarły pomimo młodzieńczych lat (23) wyróżniał się niepospolitemi zaletami serca i umysłu i zdążył dług Ojczyźnie służbą w szeregach spłacić. Miał stopień sierżanta. We wrześniu r.z. został nauczycielem w Polichnie, z zapałem oddając się pracy wychowawcy. Dowodził tamże strażą ogniową. Zmarł wskutek zakażenia krwi z oparzeń doznanych podczas pożaru domu w nocy z 12 na 13-go maja. Byłby nie zginął, gdyby nie ohydne zachowanie się ludności miejscowej"17.

\footnotetext{
${ }^{13}$ R. M i c hal s ki, Rola wychowawcza zabytków regionalnych, GK 1937, nr 19, s. 3.

${ }_{14}$ Strajk nauczycieli w Koninie, GK 1922, nr 3, s. 3.

15 Niezwykła sprawa, tamże, nr 34, s. 2.

16 Tamże, s. 2.

17 Pogrzeb ś.p. Aureljusza Wiśniewskiego, tamże, nr 22, s. 3.
} 
Dla redakcji "Głosu Konińskiego” godne pochwały okazało się zachowanie nauczycieli z Goliny, o którym wspomniano na łamach gazety. 16 grudnia 1923 r. nauczyciele miejscowej szkoły wystawili przedstawienie Sieroszewskiego pt. „Bolszewicy”, z którego zebrano około 20 milionów marek. Za zebrane pieniądze zakupiono mąkę, z której wypieczono kilkadziesiąt bochenków chleba i rozdano najbiedniejszym ${ }^{18}$.

Podkreślano także zaangażowanie nauczycieli w akcje o charakterze patriotycznym, jak np. zbiórki na cele narodowe. W Tuliszkowie - przewodniczący Ogniska Nauczycielskiego, a zarazem kierownik szkoły w Kiszewach zwrócił się do nauczycieli szkół z terenu miasta i gminy Tuliszków, aby popierali polskie lotnictwo. W treści odezwy napisano: „Ojczyzna nasza, by mogła spełnić zadania obrony swych granic w przyszłej wojnie, musi posiadać silną flotę powietrzną. W zaopatrzeniu Państwa w odpowiednią ilość samolotów winno przyjąć udział całe społeczeństwo nasze. Na czele społeczeństwa musi stanąć inteligencja pracująca, a w pierwszym rzędzie Nauczycielstwo, by swym przykładem pociągnąć szersze masy ludu naszego, jeszcze dziś mało uświadomionego do ofiarności na cele Państwowe"19.

Zawód nauczyciela należy do tych, w których konieczne jest ciągłe doskonalenie, ciągłe pogłębianie swojej wiedzy. W okresie dwudziestolecia międzywojennego doskonałą ku temu okazją były kursy wakacyjne organizowane dla nauczycieli poszczególnych przedmiotów. 8 sierpnia 1928 r. kurs taki został uruchomiony w Koninie dla nauczycieli polonistów. Wzięło w nim udział 48 nauczycieli, z czego ponad połowę stanowili nauczyciele z powiatu konińskiego, pozostali przyjechali do Konina z różnych stron Polski. Początkowo miało w nim uczestniczyć 40 nauczycieli, jednakże w odpowiedzi na duże zainteresowanie zwiększono liczbę do 48. Ponad pięćdziesięciu nauczycieli nie zostało na kurs przyjętych. Oprócz wykładów i ćwiczeń, kurs był doskonałą okazją do wymiany doświadczeń pomiędzy nauczycielami. Uczestnicy odwiedzili między innymi Kruszwicę i spotkali się z konińską pisarką Zofią Urbanowską. Autor tego artykułu był pod wrażeniem, że tak duża liczba nauczycieli pragnie $w$ okresie swojego wypoczynku szkolić się i podnosić swój poziom wiedzy: „Naprawdę podziwiać należy pęd nauczycielstwa szkół powszechnych do dalszego kształcenia się. Podziwiać należy ten objaw tem więcej, że kurs ten nie jest obowiązkowy, nie daje nauczycielstwu żadnych uprawnień, pomaga mu jedynie w jego pracy zawodowej, którą usprawnia, wychodzi tedy przedewszystkiem na dobro szkoły. Kurs odbywa się w czasie feryj, a zatem w czasie wypoczynkowym dla nauczyciela, mimo to rezygnuje z odpoczynku, a spieszy po wiedzę. Społeczeństwo może być dumne z tego, może z otuchą w sercu patrzeć na przyszłość szkoły powszechnej, tej podwaliny wychowania i nauczania młodzieży, skoro ci, którym to zadanie powierza, tak są swoją misją przejęci, tak głęboko ją pojmują"20.

Na łamach „Głosu Konińskiego" pojawiały się różne artykuły dotyczące spraw nauczycieli. Publikowano nie tylko artykuły dotyczące przedsięwzięć podejmowanych przez nauczycieli, ale także te, które dotyczyły ich powinności. Przykładem

\footnotetext{
${ }^{18}$ Idźmy za przykładem, GK 1924, nr 4, s. 2.

19 Nauczycielstwo w akcji obrony powietrznej państwa, GK 1925, nr 1, s. 2.

${ }^{20}$ Kursy Nauczycielskie w Koninie, GK 1928, nr 34, s. 1-2.
} 
może być artykuł opublikowany w grudniu 1928 r. o zadaniach, jakie stoją przed nauczycielami wobec Powszechnej Wystawy Krajowej w Poznaniu. Zwłaszcza ważne było rozpropagowanie wystawy w 1929 r., która miała pokazywać Europie i Światu osiągnięcia i dorobek dziesięcioletniego, odrodzonego państwa. Przed nauczycielami postawiono konkretne zadania. „Streszczając powyższe widzimy, że nauczycielstwo polskie stoi wobec następujących obowiązków, ciążących na niem w związku z P.W.K.:

1. szerzenie $z$ ust do ust wieści o P.W.K.;

2. uświadamianie o niej młodzieży i starszych za pomocą wykładów, odczytów i pogadanek;

3. bezzwłoczne rozpoczęcie akcji oszczędnościowej, na cel zwiedzenia Wystawy;

4. stopniowe przystępowanie do organizacji wycieczek zbiorowych"21.

Za sprawą nauczycieli chciano poruszyć wszystkie warstwy społeczeństwa polskiego. Próbowano wejść nauczycielstwu na ambicje, porównując pracę na rzecz P.W.K do walki. „Praca dla Powszechnej Wstawy Krajowej jest zaszczytną walką o imię Polski, o jedność narodową, o wiarę we własną tężyznę, o patriotyzm gospodarczy. W walce też żołnierz - wychowawca iść musi na przedzie"22.

„Pierwszym nauczycielem” Polski zwykło się określać ministra oświaty. W II RP był to minister wyznań religijnych i oświecenia publicznego. 4 sierpnia 1931 r. zmarł minister Sławomir Czerwiński. O fakcie tym „Głos Koniński” poinformował w sposób bardzo lakoniczny, ograniczając się do podania daty i przyczyny śmierci oraz krótkiej notki biograficznej ${ }^{23}$. Treść tego komunikatu była zbieżna $z$ informacjami pojawiającymi się w innych dziennikach i tygodnikach ukazujących się w różnych miastach Polski. Jest to fakt nieco zaskakujący, że redakcja „Głosu Konińskiego" nie poświęciła osobie zmarłego ministra więcej uwagi, więcej miejsca na łamach gazety. Sławomir Czerwiński był związany z Koninem i regionem. Urodził się w Sompolnie (30 km od Konina), a przez dwa lata (1910-1912) był nauczycielem w Szkole Handlowej w Koninie ${ }^{24}$.

\section{Informacje z życia szkół}

W roku 1923 „Głos Koniński” informował o ukończeniu konińskiego gimnazjum przez pierwszy rocznik uczniów. Nic więc dziwnego, że uroczystość ta miała bardzo podniosły charakter. Oprócz maturzystów, obecni byli ich rodzice, duchowieństwo, władze miejskie i oświatowe. „[...] uroczystość wręczenia matur, zagajona podniosłem i treściwem przemówieniem dyrektora Gimnazjum p. Hulewicza, któremu przypadła w udziale zaszczytna dla dyrekcji i ciała Pedagogicz-

${ }^{21}$ Zadania nauczycielstwa wobec P.W.K, tamże, nr 48, s. 1-2.

${ }^{22}$ Tamże, s. 1.

${ }^{23}$ Zgon min. Czerwińskiego, GK 1931, nr 33, s. 1.

${ }^{24}$ P. G ołd y n, Sławomir Czerwiński (1885-1931) - nieco zapomniany minister oświaty, „Koniński Kurier Oświatowy" 2011, nr 2, s. 16-17. 
nego, a ważne dla społeczeństwa zadanie pierwsze w naszej uczelni rozdanie matur swoim wychowankom, streszczającem w sobie krótką historję szkoły, stan jej obecny i zamiary na przyszłość i zakończył apelem do społeczeństwa o moralne i materialne poparcie "jednej z najstarszych w Polsce uczelni średnich"25. Wszyscy abiturienci zostali wymienieni z nazwiska, co z resztą było wówczas praktyką dość powszechną. Szkołę ukończyli: Sławomir Badyński, Marian Bogumił Duszyński, Jan Działak, Mikołaj Grętkiewicz, Kazimierz Jankowski, Józef Kałużny, Wiktor Kąkolewski, Karol Stefan Radoch, Stanisław Franciszek Wiśniewski, Włodzimierz Wiszniewski, Stefan Wrzesiński. Trzeba dodać, za autorem informacji, że szkołę ukończyło 11 spośród 20 uczniów. Fakt ten był spowodowany wcześniejszym opuszczeniem szkoły bądź niedopuszczeniem do egzaminów ${ }^{26}$.

W roku 1923 konińskie szkoły średnie stanęły przed szekspirowskim dylematem „być albo nie być”. Obie szkoły były niepaństwowe i utrzymywały się jedynie z opłat wnoszonych przez uczniów. Los tych szkół nie był obojętny ani społeczeństwu, ani władzom powiatowym. Na początku września 1923 r. zwołane zostało specjalne posiedzenie konińskiego Sejmiku powiatowego, gdyż: „całe szeregi naszej młodzieży mogły pozostać bez nauki, a dzisiejsze warunki ekonomiczne nie pozwoliłyby zwłaszcza młodzieży uboższej kształcić się gdzieindziej"27. Podczas tej specjalnej sesji radni przyjęli dwie ważne uchwały, które miały stać się gwarantami funkcjonowania obu szkół w mieście. W pierwszej Sejmik zobowiązał się „do czasu upaństwowienia przejąć na etat i pod zarząd Sejmiku powiatowego Konińskiego, Polskie Szkoły Średnie w Koninie t.j. Gimnazjum Męskie Humanistyczne i Gimnazjum Żeńskie im. Królowej Jadwigi, począwszy od 1 września 1923 r. i pokrywać rzeczywiste koszta utrzymania tychże do wysokości 50\% z wyłączeniem kosztów inwestycji i budowy”28. Z kolei w drugiej radni zadeklarowali: „Zwrócić się do władz państwowych o upaństwowienie polskiego Gimnazjum Humanistycznego Męskiego w Koninie, poczem Sejmik obowiązuje się ponieść z funduszów sejmikowych całkowite koszta utrzymania tegoż Gimnazjum od chwili upaństwowienia nie dłużej jak w ciągu lat 4-ch"29.

Autor tego artykułu nie omieszkał zauważyć, że głosowanie nad powyższymi uchwałami nie przebiegało jednogłośnie, a trzech radnych było przeciwko. Uznał, że nie rozumieją doniosłości potrzeb szkół. Na zakończenie obrad wybrano Komisję do Zarządu Szkołami Średnimi w Koninie ${ }^{30}$.

Jednym z istotnych elementów informacji z życia szkół był ten związany z otwieraniem nowych placówek. Dla ówczesnego społeczeństwa szkoła była ważnym elementem kształtowania tożsamości. Nie dziwi więc fakt, że po ponad stu latach niewoli i niemożności uczenia się w polskich szkołach, po odzyskaniu niepodległości przystąpiono do budowy szkół. Niemal w każdej większej miejscowości istniała potrzeba funkcjonowania takiej placówki i budynku.

\footnotetext{
${ }^{25}$ Pierwsi abiturienci Gim. Humanistycznego w Koninie, GK 1923, nr 25, s. 2.

26 Tamże, s. 2.

27 T. B., Doniosła uchwała, tamże, nr 36, s. 1.

28 Tamże.

29 Tamże.

30 Tamże.
} 
Fakt ten zdaje się potwierdzać krótka notka prasowa, której nadano znaczący tytuł: „I Lądek wreszcie buduje szkołę...”. W tym krótkim tekście opisano dotychczasowe warunki funkcjonowania miejscowej szkoły oraz uzasadniano potrzebę budowy nowego gmachu: „[...] kwestia lokalowa szkoły naszej przedstawia się okropnie. Proszę wyobrazić sobie szkołę o pięciu nauczycielach rozrzuconą dosłownie po całej osadzie, lokale bez własnych sieni, podwórek, boisk, itp., przy bruku samym, z terkoczącymi co chwila wozami, itd. Wprost mówić się nie chce o tej „parodii” szkoły... tej bieganinie nauczycieli z jednej klasy do drugiej po całej osadzie. Społeczeństwo miejscowe oddawna współczuło nauczycielstwu, no i przede wszystkiem swym dzieciom i na apel przystąpienia samorzutnego do budowy szkoły chętnie pośpieszyło z datkami”"31. Z powyższego opisu wynika, że warunki nauczania były w Lądku dość dramatyczne. Na początku 1938 r. część gmachu została wybudowana, jednakże budowa nie była jeszcze ukończona. Większość środków finansowych na jej realizację pochodziło z dobrowolnych składek poszczególnych mieszkańców i miejscowych organizacji.

Z okazji otwarcia nowego gmachu gimnazjum w Koninie opublikowano na łamach „Głosu Konińskiego" specjalnie na tę okoliczność napisany wiersz autorstwa Lucyny Ścińskiej:

Oto Duch Boży dziś ten gmach święci,

Niech się oświata w nim krzewi, rozrasta,

Niech pisze daty wiekowej pamięci,

Trudy Zarządów powiatu i miasta...

Już pokonano przeszkody ogromne,

Odwaga czynu ponad szczyty sięga...

Przed nami wzrosło dzieło wiekopomne,

Które dziś wieńczy symboliczna wstęga

I myśl zdumiona przeszłość dziejów mierzy,

Serce rozpiera duma i pożytek,

Że wiedzy ojczystej nasi Pionierzy

Wybudowali wspaniały przybytek

Szkoło! Twoi wyznawcy, przyjaciele!

W dniu Twoich święceń składają życzenia,

Wierząc, że spełnisz nasze główne cele,

Pod przewodnictwem Wielkiego Imienia...

Wdzięczni maturzyści zacnym orszakiem

Broń prezentują przed Tobą służbowo...

Żeś wyróżniła ich pod swoim znakiem,

Przygotowując do czynu wzorowo.

Ty na ich czołach płomyki ogniste,

Jak konsekracji położyłaś tchnienie,

Akty swej prawdy dałaś im strzeliste

I miłość piękna, i wiedzy pragnienie...

${ }^{31}$ I Lądek wreszcie buduje szkołe..., GK 1938, nr 2, s. 4. 


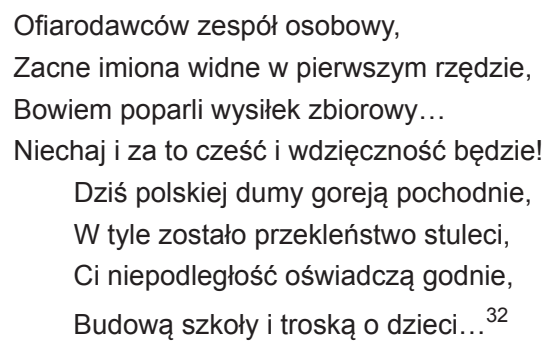

O tym, jak ważnym wydarzeniem dla koninian było otwarcie nowego gmachu gimnazjum świadczy powyższy wiersz, ale także tytuł artykułu opisującego to wydarzenie Uczelnia konińska w nowej siedzibie, jak również skład komitetu budowy, na czele którego stał Stanisław Mańkowski - senator. Po jego śmierci komitetowi przewodniczył Marian Koczorowski - starosta koniński. Na czele komitetu wykonawczego stanął wicestarosta Sulkowski, a zastąpił go później Wincenty Grętkiewicz - poseł na Sejm i burmistrz Konina. Budowę rozpoczęto wiosną 1936 r. Jednym z impulsów do podjęcia działań w tym zakresie było zmieniające się prawo oświatowe oraz chęć podtrzymania w mieście czteroklasowego gimnazjum i otrzymania koncesji na prowadzenie przy nim liceum ogólnokształcącego. Po niespełna dwóch latach budowy, w styczniu 1938 r. oddano do użytku gmach, w którym mieściło się 8 klas szkolnych, 6 pracowni połączonych z 6 gabinetami. Gimnazjum posiadało własną salę gimnastyczną, „rozbieralnię”, aulę z kabiną projekcyjną, świetlicę oraz pokoje nauczycielskie ${ }^{33}$.

W roku 1938 zakończyła w Koninie swoją działalność Szkoła Podoficerska dla Małoletnich. Uroczystość ta odbyła się 13 czerwca, a decyzję o jej likwidacji podjęły władze wojskowe. Dla mieszkańców Konina i powiatu konińskiego była to swoista strata. Szkoła ta przysparzała miastu prestiżu ${ }^{34}$.

O zamiarze otwarcia tej szkoły również można było przeczytać w „Głosie Konińskim”. Pod koniec 1928 r. ukazała się krótka notka zatytułowana Szkoła Podoficerska w Koninie. Informowano w niej o otwarciu szkoły i organizacji nauki, która trwać miała trzy lata. Po zakończeniu nauki w Koninie wychowankowie trafiali do armii, gdzie mieli odsłużyć dziewięć lat jako żołnierze zawodowi. Autor podkreślał również, że jest to pierwsza tego typu szkoła w Polsce. Przyjmowano do niej uczniów po ukończeniu piętnastego roku życia i ze świadectwem czwartej klasy szkoły powszechnej. Wszystkie dokumenty należało składać w Departamencie Piechoty Ministerstwa Spraw Wojskowych ${ }^{35}$.

Samo otwarcie nastąpiło w ostatnią niedzielę listopada 1928 r., a „przechodniów spieszących do świątyń, lub przypadkiem znajdujących się na ulicach Konina uderzył w ubiegłą niedzielę przed południem niewidziany dotąd w naszym mieście widok. Oto przy dźwiękach orkiestry maszeruje oddział złożony z przeszło

\footnotetext{
${ }^{32}$ L. Ś c i ń s k a, Na dzień poświęcenia nowego gmachu gimnazjum w Koninie, tamże, s. 2.

${ }^{33}$ Uczelnia konińska w nowej siedzibie, tamże, nr 3, s. 1-2.

34 Pożegnanie Szkoły Podoficerskiej, tamże, nr 25, s. 2.

35 Szkoła Podoficerska w Koninie, GK 1928, nr 47, s. 2.
} 
stu chłopców, w wieku najwyżej lat czternastu, jednolicie a schludnie ubranych w mundury żołnierskie. Krok równy, miarowy, dzielna postawa, a mina prawie, że... marsowa, bruk dudni aż miło"36. Szkoła ta i jej uczniowie na dekadę wpisali się w dzieje miasta Konina.

„W nocy z soboty na niedzielę, dnia 21 listopada b.r. o godz. $1 \mathrm{~m} .41$ pociągiem od strony Poznania przybył do Konina Pan W. Ambroziewicz, Kurator Okręgu Szkolnego Warszawskiego" ${ }^{37}$. Takim zdaniem rozpoczęła się relacja z wizyty kuratora w Koninie, zamieszczona w 48 numerze „Głosu Konińskiego” z 1937 r. W czasie swego pobytu w powiecie konińskim dokonał wizytacji nowo wybudowanych szkół w Morzysławiu, Wilczynie i Ostrowitem. Spotkał się także z konińskimi harcerzami. Wieczorem, w lokalu Towarzystwa Wioślarskiego w Koninie, spotkał się nauczycielami zrzeszonymi w Związku Nauczycielstwa Polskiego. Podczas zamkniętego spotkania, przy herbatce, władze związku zapewniły, że miejscowe nauczycielstwo nie będzie szczędziło wysiłków w pracy dla dobra polskiej szkoły. „Wzruszający moment pobytu Pana Kuratora w terenie mamy do zanotowania w Tuliszkowie, gdzie Pan Kurator - z mocy przysługującego Mu prawa - nadał miejscowej 7-klasowej szkole powszechnej nazwę „Imienia Powstańców 1863 r.”, a ofiarowane mu przez dziatwę szkolną kwiaty złożył u stóp pomnika, wygłaszając pełne patriotyzmu i czci dla poległych bohaterów narodowych - przemówienie do młodzieży szkolnej"38. Wizytację szkół w sąsiednim powiecie kolskim uniemożliwiło pilne wezwanie kuratora do powrotu do Warszawy.

„Radosną chwilę przeżyła nasza szkoła w dniu 5 czerwca 1928 r. Momentem tym była chwila otwarcia szkolnego radia, które zakupiono drogą składek rodziców. Najwydatniej akcję tę poparł miejscowy Zw. Strzelecki, który ofiarował na ten cel 20 zł. Największa sala szkolna nie mogła objąć wszystkich rodziców, którzy przyszli obejrzeć radioaparat kupiony za ich groszowe składki i miło było widzieć błogo uśmiech zadowolenia na ustach wszystkich, gdy z głośnika usłyszeli słowa speakera pozdrawiające rodziców i dzieci szkoły krzymowskiej i życzące im dobrego odbioru". W ten sposób relacjonowano zakup odbiornika radiowego dla szkoły w Krzymowie. Podczas tej podniosłej dla placówki uroczystości obecny był między innymi inspektor szkolny, Stanisław Mijas. W krótkim przemówieniu podniósł sprawę znaczenia radia, ze szczególnym uwzględnieniem jego roli w szkole. Kierownik szkoły złożył sprawozdanie z zakupu radia. Uczniowie natomiast podziękowali Związkowi Strzeleckiemu za ten miły prezent ${ }^{39}$.

Bywało również tak, że o tym, co działo się w szkołach na terenie powiatu konińskiego informowali sami nauczyciele bądź osoby związane z tą szkołą. Przykładem może być informacja zatytułowana Z życia szkoły w Grodźcu. W pierwszej części tej notatki poinformowano o podniesieniu szkoły powszechnej do rangi szkoły siedmioklasowej oraz przebudowie i dobudowie pomieszczeń z tego faktu

${ }^{36}$ Otwarcie Szkoły Podoficerskiej dla małoletnich w Koninie, tamże, nr 49, s. 1.

${ }^{37}$ Z pobytu Kuratora Okręgu Szkolnego Warszawskiego Pana W. Ambroziewicza w Koninie, GK 1937, nr 48, s. 1.

${ }^{38}$ Tamże.

${ }^{39}$ Radio w szkole krzymowskiej, GK 1938, nr 25, s. 3. 
wynikających. Potem zrelacjonowano w kilku zdaniach wizytę w szkole ks. bpa Karola Radońskiego - ordynariusza diecezji włocławskiej. Zauważono również, że problemem pozostaje ograniczony dostęp do oświaty dzieci z ubogich rodzin. Aby temu w jakiś sposób zapobiec, $z$ inicjatywy kierownika szkoły p. M. Wichlińskiego utworzony został Komitet Zabaw Dochodowych i Zbiórek. Głównym zadaniem było organizowanie imprez, z których dochód przeznaczony był na wsparcie uczniów z ubogich rodzin ${ }^{40}$.

"Głos Koniński” poinformował swoich czytelników o obywatelskiej postawie uczniów szkoły powszechnej w Pyzdrach. Otóż uczniowie tej szkoły zebrali pieniądze i dokonali zakupu obligacji Pożyczki Narodowej. Powiadomili o tym również ministra Stefana Starzyńskiego: „I my dzieci 7-mio klasowej szkoły powszechnej w Pyzdrach, zakupiliśmy 100 zł. obligację Pożyczki Narodowej, płatną w dwóch ratach. [...] Rozumiemy, że Polska od wszystkich obywateli wymaga spełnienia obowiązku, a więc, choć swych pieniędzy nie mamy, przeznaczamy zysk ze sklepiku Spółdzielni Uczniowskiej na kupno obligacji, gdyż pragniemy, by nasza Ojczyzna była wielka i silna"41.

Dość nietypową informację dotyczącą życia szkoły zamieszczono w 23 numerze "Głosu Konińskiego" z 1938 r. Pod niewiele mówiącym anonsem prasowym zatytułowanym Podziękowanie znajduje się następująca treść: „Kierownictwo Publicznej Szkoły Powszechnej w Szetlewku gm. Trąbczyn, powiatu konińskiego dziękuje tą drogą panu Sebastjańskiemu Ryszardowi, marynarzowi statku S.S. Katowice, za łaskawe ofiarowanie żółwia afrykańskiego dla użytku szkoły. Ten obywatelski czyn pana Ryszarda Sebastjańskiego należy podkreślić z uznaniem" ${ }^{42}$.

\section{Plany oświatowe}

Powiat koniński był w dwudziestoleciu międzywojennym zdominowany przez rolnictwo. Nic więc dziwnego, że na łamach "Głosu Konińskiego" postulowano utworzenie na tym terenie szkoły rolniczej, w której miejscowa młodzież mogłaby zdobywać odpowiednie wykształcenie. Według autora inicjatorem założenia szkoły powinny być władze powiatowe, a konkretnie Sejmik Powiatowy. Do szkoły mieli być przyjmowani uczniowie w wieku od 18 do 21 lat. Aby szkoła była jak najbardziej dostępna dla młodzieży „a) musi być tania, b) poziom wymagania od nowowstępujących nie może przekraczać programu szkoły powszechnej i c) czas nauki nie może być długi”ł3. Za przykład stawiano szkołę rolniczą w Pszczelinie, która prowadziła zajęcia edukacyjne w formie kursów ${ }^{44}$.

${ }^{40}$ S. Makowijczuk, Z życia szkoły w Grodźcu, GK 1931, nr 42, s. 2.

${ }^{41}$ Czyn obywatelski dzieci szkoły powszechnej w Pyzdrach, GK 1933, nr 41, s. 2.

${ }^{42}$ Podziękowanie, GK 1938, nr 23, s. 3.

${ }^{43}$ K. D., Zawodowa Szkoła Rolnicza, GK 1925, nr 7, s. 1-2.

${ }^{44}$ Tamże, s. 1. 
Z początkiem 1928 r. w „Głosie Konińskim” ukazał się ciekawy artykuł, w którym autor sugerował utworzenie jednej szkoły średniej przynajmniej dla uczniów z trzech powiatów - konińskiego, słupeckiego i kolskiego. Wychodził z założenia, że szkoły średnie funkcjonujące $w$ wymienionych powiatach nie spełniają swojej misji ani pod względem dydaktycznym, ani organizacyjnym. Trudna sytuacja materialna powodowała ciągłe podnoszenie opłat za naukę, co z kolei przedkładało się na niemożność płacenia przez rodziców czesnego. Brak środków materialnych to również niższe pensje dla kadry nauczycielskiej, stąd szczupłe grona pedagogiczne i niekoniecznie dobrze przygotowane do pracy. To z kolei miało wpływ na poziom nauki. Dodatkowo pewne obowiązujące przepisy prawne, które ograniczyły zainteresowanie szkołami średnimi, przyczyniały się do zmniejszania liczby uczniów. Autor sugerował zatem uruchomienie jednej upaństwowionej szkoły średniej. Co oczywiste, miała ona działać w Koninie, który miał nie tylko centralne położenie względem Słupcy, Koła czy nawet Turku, ale także dogodne rozwiązania komunikacyjne. „Korzyść z podobnego kroku ogromna, fundusze bowiem przeznaczone wówczas przez poszczególne samorządy miejskie i powiatowe mogłyby być daleko więcej celowo zużyte. Liczniejsza frekwencja w szkole zapewniałaby przy mniejszej opłacie wpisowej pokrycie z takowej utrzymania dobrze płatnego, a więc i dobranego personelu nauczycielskiego, zasiłki zaś obrócone by mogły być na cele naukowe oraz na pomoc dla dziatwy szkolnej, której wówczas możnaby w znacznym stopniu ułatwić ukończenie szkoły średniej, większy procent uczniów możnaby zwolnić od opłaty szkolnej przez co znowu możnaby ukryte wśród najbiedniejszych warstw społecznych prawdziwe talenty pchnąć na racjonalną drogę rozwoju duchowego"45.

Oczywiście była to wizja niewykonalna, z kilku względów. Jednym z nich była z pewnością ambicja. Żaden z tych ośrodków nie zrezygnowałby z posiadania własnej szkoły średniej, chociażby ze względu na prestiż.

\section{Oświata pozaszkolna}

Ważnym problemem edukacyjnym II RP była oświata pozaszkolna. Okres zaborów, a później także wydarzenia wojenne sprawiły, że wielu młodych ludzi pozostawało bez wykształcenia. Ich wiek nie pozwalał już na zasiadanie w ławach szkolnych, wobec powyższego uzupełniali wykształcenie w ramach oświaty pozaszkolnej.

Przy działającej w powiecie konińskim Radzie Szkolnej Powiatowej utworzony został Wydział Oświaty Pozaszkolnej, w skład którego weszli przedstawiciele nauczycielstwa i różnych sfer społecznych. Celem głównym Wydziału było organizowanie oświaty pozaszkolnej na terenie powiatu konińskiego. Pierwszym z wymownych elementów tego działania było uruchomienie 27 lutego 1927 r. Uni-

\footnotetext{
${ }^{45}$ Parę stów o Szkole Średniej w Koninie, GK 1928, nr 8, s. 1-2.
} 
wersytetu Ludowego, który prowadził zajęcia w budynkach parafialnych w Koninie, w każdą sobotę po wieczornej mszy świętej. Przy Uniwersytecie uruchomiono bibliotekę. Uniwersytet przejął również zarząd nad biblioteką należącą dotąd do Towarzystwa Dobroczynności ${ }^{46}$.

Ciekawy kurs oświaty pozaszkolnej odbył się w Słupcy w dniach 28 listopada - 4 grudnia 1933 r. Kurs ten zorganizowano zarządzeniem Kuratorium Oświaty Okręgu Szkolnego Warszawskiego, według następującego programu: „1) P. H. Hoftmanowa, Psychologiczne podstawy pracy oświatowej; 2) p. St. Tazbir, Socjologiczne podstawy pracy oświatowej; 3) p. M. Moczydłowska-Niekraszowa, Przegląd form pracy oświatowej; 4) p. St. Tazbir, Rola świetlicy w budzeniu i zaspokajaniu kulturalnych potrzeb środowiska; 5) p. J. Święcicka, Czytelnictwo i bibliotekarstwo; 6) p. Olszewski, Chóry ludowe; 7) p. J. Rączka, Samorząd terytorialny a wychowanie państwowo-obywatelskie; 8) p. A. Morkowski, Idea ochrony państwa a Związek Strzelecki; 9) p. poseł Maria Jaworska, Cele i zadania oświaty pozaszkolnej oraz jej rola w wychowaniu państwowym obywateli”"47.

Sporo miejsca oświacie pozaszkolnej poświęcono w drugim numerze „Głosu Konińskiego" z 1934. Z ideą tej oświaty oraz z celami, jakie sobie ona stawia zapoznawał czytelników M. Kozłowski - inspektor oświaty pozaszkolnej na Obwód Szkolny Koniński. Swoją uwagę skupił przede wszystkim na środowisku wiejskim i szczególnej konieczności realizacji tam oświaty, aby młodzieży wiejskiej dać szansę zdobycia wykształcenia czy wyuczenia jej jakiegoś rzemiosła. Uważał także, że oświata pozaszkolna podniesie wieś zarówno od strony zewnętrznej (murowane domy, dobre zbiory zbóż) i wewnętrznej (wyższa kultura, czystość, wyższy poziom etyczny mieszkańców). Realizatorami zajęć w ramach oświaty pozaszkolnej byli przede wszystkim miejscowi nauczyciele, jednakże nie byli oni w stanie zapewnić wszystkich potrzeb i pomóc w tym zakresie wszystkim potrzebującym. Dlatego też autor apelował do społeczeństwa o wsparcie merytoryczne i finansowe ${ }^{48}$.

Odpowiedzią na ten apel były działania podejmowane w terenie, jak chociażby w Ślesinie, gdzie zadania oświaty pozaszkolnej realizowane były wielotorowo. Pierwszym były kursy dokształcające. Jeden z nich odbył się w okresie od 1 do 17 lutego 1934 r., a wzięło w nim udział 28 słuchaczy. Uczestnicy tego kursu w następnym roku mieli uczestniczyć w wykładach, a później przystąpić do egzaminów potwierdzających ukończenie siedmioklasowej szkoły powszechnej. Drugą możliwością zdobywania wiedzy był uniwersytet niedzielny, prowadzony w niedzielę po południu. Głównymi prowadzącymi wykłady byli nauczyciele szkoły powszechnej w Ślesinie wsparci przez miejscowych lekarzy: J. Krysgela i W. Uniejewskiego. Absolwenci tego uniwersytetu skupieni byli w kole absolwentów, uczestnicząc w kursach i wykładach, pogłębiających ich wiedzę ${ }^{49}$.

46 Uniwersytet Ludowy w Koninie, GK 1927, nr 8, s. 1-2.

${ }^{47}$ Kurs oświaty pozaszkolnej w Słupcy, GK 1934, nr 1, s. 4.

48 M. Ko zło w s ki, Oświata pozaszkolna, tamże, nr 2, s. 1-2.

49 Oświata pozaszkolna w Ślesinie, tamże, nr 17, s. 3. 


\section{„Szkoła i nauczyciel”}

Tak zatytułowana była specjalna rubryka, która pojawiła się z początkiem roku szkolnego 1932/1933 na łamach „Głosu Konińskiego”. W niej podejmowano różne tematy związane ze szkołą i oświatą, szczególnie w kontekście regionalnym. Dział ten był bardzo życzliwie przyjmowany zarówno przez nauczycieli, jak i ogół społeczeństwa.

Już w pierwszej rubryce omawiano kwestie związane z dożywianiem dzieci w szkole ${ }^{50}$ oraz informowano o miesięczniku szkół powszechnych powiatu konińskiego wydawanym przez uczniów szkoły w Ślesinie we współpracy z uczniami innych szkół51. Również nauczyciele powiatu konińskiego podjęli inicjatywę wydawania własnego czasopisma. Był to miesięcznik, który ukazywał się pod tytułem „Nasza Praca”. W dziale „Szkoła i nauczyciel” poinformowano o ukazaniu się pierwszego numeru, podano skład komitetu redakcyjnego i redakcji. Zastanawiano się również, czy sensowne było podejmowanie takiej inicjatywy, skoro na rynku jest już sporo tytułów pedagogicznych, a w kraju panuje kryzys gospodarczy. Czasopismo miało być miejscem wymiany poglądów, doświadczeń, miejscem, w którym publikowane były również przykłady lekcji. Poza tym w gazecie znalazły się między innymi również takie działy, jak: dział samokształceniowy, oświata pozaszkolna czy życie związkowe. Gazeta miała być, jak pisała jej redakcja, „złotą nicią, łączącą nasze wspólne wysiłki, w celu stałego podnoszenia szkolnictwa powszechnego do najwyższego poziomu"52.

Rubryka ta stała się swoistym forum informacyjnym, gdzie pojawiały się notatki dotyczące również działalności instytucji „około oświatowych”, jak np. ZNP czy innych. W 1933 r. z okazji rocznicy wybuchu powstania styczniowego środowiska nauczycielskie podejmowały inicjatywy związane z uczczeniem tej rocznicy. Na terenie powiatu znajdowała się miejscowość Ignacewo, w której 8 maja 1863 r. odbyła się jedna z najkrwawszych bitew powstania styczniowego. W 1917 r. mieszkańcy postawili tam skromny pomnik w kształcie krzyża. Siedemdziesiąta rocznica stała się doskonałą okazją do renowacji pomnika. $Z$ tego względu Związek Nauczycielstwa Polskiego, Oddział Powiatowy w Koninie wydał odezwę do nauczycieli, wzywając ich do zaangażowania w zbiórkę pieniędzy na powyższy cel: „Oddział Powiatowy Związku Nauczycielstwa Polskiego w Koninie, wziąwszy w opiekę pomnik powstańców w Ignacewie, w najbliższych dniach na terenie całego powiatu podejmie akcję w celu zebrania odpowiedniego funduszu na odrestaurowanie i ogrodzenie pomnika. Ogniska ZNP przystąpią do zorganizowania lokalnych Komitetów zbiórki na pomnik powstańców w Ignacewie. Mamy głębokie przekonanie, że społeczeństwo chętnie pospieszy z współpracą, że nikt nie odmówi datku na pomnik żołnierzom-bohaterom, którzy nie wchodzili w układy z Moskalem, nie pytali, jakie siły prowadzi nieprzyjaciel, nie błagali wrogów o łaskę, lecz ginęli z tem przeświadczeniem, a ich krew nie pójdzie na marne, że ich krew wróci życie Rzeczpospolitej Polskiej"”3.

${ }^{50}$ O dożywianie niezamożnej dziatwy szkolnej, GK 1933, nr 3, s. 2.

51 „Nasz Światek” miesięcznik młodzieży szkół pow. powiatu konińskiego, tamże, s. 2.

52 "Nasza Praca”, tamże, nr 16, s. 2.

53 Tym, którzy mieli odwagę zginąć za ojczyznę, tamże, nr 4, s. 3. 
W rubryce tej, wrócono również do tematu współpracy domu ze szkołą. Autor chwalił rodziców, którzy wykazywali zainteresowanie swoim dzieckiem i wspierali szkołę w wychowaniu. Omówiona została kwestia tworzenia Kół Rodzicielskich, „które wchodzą czynnie w skład szkoły jako całości i wspólnemi omawianiami różnych niedomagań znajdują wyjście odpowiednie, podają projekty pracy wychowawczej i realizują je wspólnie z nauczycielami, tworzą fundusze, któremi zasilają potrzeby szkoły, rozwijają akcję pomocy biedniejszym, a nawet prowadzą wspólnie charakterystykę poszczególnych uczniów. Gdzie dobór rodziców jest mało inteligentny, tam tworzą kursy uświadamiające dla rodziców i opiekunów ażeby móc ich później lepiej wykorzystać przy współpracy wychowawczej"54.

Dział ten kontynuowany był także w następnym roku szkolnym, jednakże już nie tak regularnie jak w pierwszym roku funkcjonowania. Pojawiało się wówczas więcej artykulików o charakterze ogólnym niż szczegółowym.

\section{Tydzień Szkoły Powszechnej}

W drugiej połowie lat trzydziestych, zaczęto w Polsce w październiku obchodzić „Tydzień Szkoły Powszechnej”, podobnie jak „Tydzień Morza” czy „Tydzień Lotnictwa”. W tym samym też czasie, do roku 1938, każdy 40 numer „Głosu Konińskiego" niemalże w całości poświęcony był sprawom szkolnym, oświatowym i pedagogicznym. Wzywano wówczas do popierania budowy szkół powszechnych, aby w nich realizować naczelne zadania wychowawcze, przygotowujące młode pokolenia do: „utrwalenia bytu i potęgi Rzeczypospolitej, podniesienia kultury ogólnej kraju, zapewniania bezpieczeństwa granic państwa”. Udowadniano, że szkoła jest dobrodziejstwem, że coraz większa ich ilość pozwoli objąć oświatą wszystkie dzieci. To z kolei zaowocuje wychowaniem dobrych obywateli, służących ojczyźnie.

W tych niemalże „specjalnych wydaniach” znajdowano również miejsce na publikowanie twórczości uczniowskiej czy nauczycielskiej. W 1936 r. zamieszczono opowiadanie autorstwa jednego z uczniów konińskiej szkoły powszechnej55, a także nauczyciela, który rozważał kwestie związane z troską o zdrowie i oświatę dla młodzieży ${ }^{56}$.

Podsumowując powyższe rozważania, należy stwierdzić, iż redakcja „Głosu Konińskiego" doskonale zdawała sobie sprawę, że ma do spełnienia pewną misję w obszarze oświatowo-pedagogicznym. Wyraźnie podkreśla to fragment artykułu opublikowanego na łamach gazety już w 1922 r. „Na łamach nieomal każdego numeru „Głosu Konińskiego” czytamy artykuły, poruszające kwestje oświaty, nauczania. Jest to całkiem zrozumiałe. Oświata, to obecnie najważniejsze i najpierwsze zagadnienie społeczne, musi więc zajmować umysły dobrze myślących obywateli. I dyskusja nad koniecznością szerzenia oświaty jest zbyteczna. Głód

\footnotetext{
54 O współpracę domu ze szkołą, tamże, nr 5, s. 2.

55 H. Kałużn y, Bajka prawdziwa, GK 1936, nr 40, s. 3.

${ }^{56}$ F. S ta c h, W trosce o zdrowie $i$ oświatę dla młodzieży, tamże, nr 40, s. 2-3.
} 
światła i nauki zaznacza się w najciemniejszych nawet warstwach społeczeństwa i jeżeli jeszcze nie słychać ogólnego wołania wsi i miasteczek: „Szkół, wiedzy nam dajcie!" to wskutek małego wyrobienia życiowego i tego, że szkoły te utrzymać musimy sami"57.

W kontekście braku dokumentów wypracowanych przez szkoły działające w okresie dwudziestolecia międzywojennego w Koninie i na terenie powiatu konińskiego, a więc kronik, protokołów rad pedagogicznych i tym podobnym, informacje zawarte na łamach prasy, a w tym przypadku "Głosu Konińskiego” stają się jedynym, w jakimś sensie najbardziej miarodajnym źródłem wiedzy o oświacie. Pojawiające się często nazwiska nauczycieli, samorządowców pozwalają określić ich zaangażowanie $w$ działania na rzecz budowy systemu oświatowego na terenie powiatu konińskiego. Owszem, konieczna jest weryfikacja niektórych faktów ze względu, chociażby, na rzetelność dziennikarską lub może czasami jej brak. Jednakże teksty poświęcone oświacie, szkolnictwu, zagadnieniom pedagogicznym, publikowane na łamach "Głosu Konińskiego" dają podstawę wyjścia do rozpoczęcia szerszych badań, dotyczących aspektów historii edukacji, a także biografii poszczególnych nauczycieli.

${ }^{57}$ J. W i ś., O biblioteki wiejskie, GK 1922, nr 11, s. 2. 